\title{
Attitudes towards Turkish and Turks in Austria: From Guestworkers to "Quasi-Foreigners" in a Changing Social Landscape
}

\author{
Johannes Woschitz
}

check for updates

Citation: Woschitz, Johannes. 2021. Attitudes towards Turkish and Turks in Austria: From Guestworkers to "Quasi-Foreigners" in a Changing Social Landscape. Languages 6: 58. https: / / doi.org/10.3390/

languages6010058

Received: 3 February 2021

Accepted: 18 March 2021

Published: 23 March 2021

Publisher's Note: MDPI stays neutral with regard to jurisdictional claims in published maps and institutional affiliations.

Copyright: (C) 2021 by the author. Licensee MDPI, Basel, Switzerland. This article is an open access article distributed under the terms and conditions of the Creative Commons Attribution (CC BY) license (https:// creativecommons.org/licenses/by/ $4.0 /)$.
Independent Researcher, Edinburgh EH11 2EW, UK; johannes.woschitz@gmx.net

\begin{abstract}
In Austria, Turkish immigrants have long suffered from the stigma of being the uneducated and unintegrated guestworker, often portrayed as marginalised and as living in parallel societies. However, second-generation Turks who were born and/or raised in Austria have challenged this stigma profoundly. This paper argues that this has led to a re-indexicalisation of Turkish in Austria. Evidence for this is drawn from two matched-guise studies $(n=226)$ that aimed to unearth the covert language attitudes of Austrian participants towards Turkish. The data presented shows that many Austrian participants still conceive of the Turkish guises in overall xenophobic terms. They were depicted as more aggressive, less educated, less integrated, more joyous of life and more family-oriented when compared to the German guises. There was, however, an age-effect indicative of changing attitudes among participants born after 1998, for whom this stereotype seems to be losing its influence.
\end{abstract}

Keywords: matched-guise test; language attitudes; guestworkers; Turks; diaspora

\section{Introduction}

Some key themes of this Special Issue are micro- and macro-level language attitudes, the negotiation of new migrant identities, translocal interconnectedness and post-spatial concepts of belonging and home. The present paper explores these in the context of the Turkish minority in Austria.

In the 1960s, in the course of the post-WWII economic boom, European countries, Austria included, signed so-called guest worker treaties with Yugoslavia and Turkey to compensate for a shortage of unskilled workers. In Austria, the treaty stipulated that blue-collar workers from these countries should be allowed to stay as long as their workforce is needed, and then return home. In practice, however, many guestworkers settled permanently, without any formal guidelines as to how they are expected to integrate.

Former Turkish guestworkers have suffered from a bad social reputation in Austria and are often portrayed by locals as "the Other", unwilling to integrate (e.g., Wets 2006; Strabac et al. 2012; Zick et al. 2008). ${ }^{1}$ Making up roughly 3\% of Austria's overall population, the Turkish minority has become an integral part of the Austrian social landscape nonetheless, and particularly, second-generation Turks have challenged the social stigma of the "Turkish guestworker" profoundly. This, I shall argue in this paper, has led to a re-indexicalisation of Turkish in Austria.

Evidence for this is drawn from two matched-guise test studies (Garrett 2010) that aimed to unearth the covert language attitudes of Austrian participants. The first study was conducted in $2015(n=155)$, and a follow-up study was conducted in $2019(n=71)$, yielding an overall sample size of 226 participants. Data collection involved recording short

1 The majority of Turkish migrants in Europe live in Germany, where similar marginalisation tendencies have been observed (e.g., Groenewold et al. 2014; Kagitcibasi 2010; Mandel 2013; Pásztor 2008). 
sections of Cinderella read in both Turkish and German by male and female bilingual secondgeneration Turks who grew up in Austria. Participants who had lived at least 3 years in Austria were then asked to judge these guises on the basis of 14 different personality traits (including aggressiveness, religiousness, economic wealth and enjoyment of life).

Dimension reduction shows that the German and Turkish guises were evaluated fundamentally differently. The Turkish guises were overwhelmingly depicted as what I shall call "archaic migrants", linked to the belief that they are aggressive, uneducated and badly integrated - a popular depiction of guestworker identities. There was, however, an age-effect that was indicative of changing attitudes towards speakers of Turkish among participants born after 1998, for whom this overall stereotype seems to be losing its influence.

My data sheds important light on the complexity behind diasporic identity construction in second-generation migrant contexts, and the paper is a case in point example that language attitudes are always subject to changing sociocultural environments. In the case of Austria, I argue that younger generations have moved away from post-WWII ideals of nation building. With a changing social landscape, the ethnicised dividing line between Austrians and ethnic Turks has blurred, and the Us/Them conceptions have begun to blur along with it.

To explore this matter at hand, I shall first give a brief historical overview of multilingual Austria and outline the important ideologies that have led to its current sociolinguistic status quo. This is followed by a section on key demographics of the Turkish minority in Austria. In the data analysis, I argue, among other things, in favour of an intricate cohort effect when it comes to prejudices towards the Turkish minority in Austria. In the discussion, these findings are related to the key themes of this issue, which include transnational belonging, the indexical construction of diasporic identities and macro-level ideologies.

\section{The Monolingual Habitus in Austria: A Brief Historical Overview}

If one is allowed to begin a paper with a crude generalisation, it would be this: in present-day Austria, the "monolingual habitus" (Gogolin 1994) reigns supreme. Austria's restrictive language policies after 1955 (de Cillia 1998; Sonntag 2010 give an overview) have actively erased what German-speaking linguists call "autochthonous" minorities, i.e., minorities under constitutional protection, and "allochthonous" minorities, i.e., recent immigrant minorities, from the linguistic landscape. At times, multilingualism was blatantly erased, as in the case of the Ortstafelsturm of 1972 in Carinthia, where bilingual German/Slovene place name signs were defiled or dismantled by the local population. In Burgenland, to this date, bilingual German/Croatian place name signs are nowhere to be found, even though the Croatian minority has a subjective right to demand them in front of the state-the pressure to assimilate is too big (see de Cillia 1998, chp. 3). Recent immigrants - "allochthonous" minorities-generally have few to no rights when it comes to education in their first languages, for example, whereas autochthonous minorities at least have access to bilingual schools (although there are few in number) that grant them education in both German and their respective heritage language. In both cases, however, if one wants to climb the social ladder, one needs to bite the bullet and fully embrace German-speakerhood (de Cillia and Wodak 2006; de Cillia 1998). Similar to many other European countries, integration in Austria is equated with assimilation (Wets 2006, p. 89), and this means adopting "Austrian" values and the most important official language of all-German.

From an historical point of view, this German-centrism is a relatively young phenomenon. Austria-Hungary, and the Habsburg Monarchy in its entirety, was a distinctly multilingual monarchy (a Vielvölkerstaat), and efforts to implement German as the official state language were unsuccessful during this time (de Cillia 1998, p. 59; see also Sonntag 2010). When the monarchy collapsed in 1918, the German-speaking remnant (Deutschösterreich or Cisleithania) sought to affiliate with the German nation/nation-state in an effort 
to uphold its political significance. In the same year, the Republic of German-Austria (demokratische Republik Deutsch-Österreich) was proclaimed, with the overarching goal to become part of Germany. In the peace negotiations of 1919, however, this was denied by the allies, and the demokratische Republik Deutsch-Österreich became Republik Österreich, which went hand-in-hand with a massive loss of territory. To compensate, German became the official language for the first time in October 1919, as an index of affiliation to the German nation-state (de Cillia 1998, p. 29).

As is well known, the großdeutsche ideology, or the "German question", found its sad peak during Nazism. Even though Austria was an active perpetrator in war-related crimes during WWII, immediately after the war, it re-enacted itself as one of the first victims of Hitler (who was himself Austrian). This had to go hand-in-hand with the renunciation of the großdeutsche ideal (actively enforced by the allies by re-instantiating an independent Austrian state), even though this ideology was an important anchor point for the national self-conception of the First Austrian Republic between the two world wars.

Austria, in other words, had to reinvent itself as a nation after 1945, as the großdeutsche ideal proved unsuccessful. This took effort and time: de Cillia (1998, p. 103) cites a study conducted in 1955 according to which $46 \%$ of all Austrian respondents still considered themselves to be members of the German Volk. However, measures like the publishing of the first Austrian-German dictionary in 1951 contributed strongly to the emergence of a sense of national independence and unity. The Austrian-German variety became an important ideological vehicle to portray distinctive "Austrian-ness". Following de Cillia (1998, chp. 2), it assumed two main functions post-1945:

- On an international level, it was utilised to index ideological distance from Germany. Structural similarities between German Standard German and Austrian German notwithstanding, differences between the two have constituted an axis of differentiation (Gal 2016) by which national differences (perpetrator/victim and other dichotomies) can be expressed via variety differences;

- On a national level, it was a means to homogenise the population of a relatively young nation-state under a single, distinct variety of German (thereby excluding autochthonous and allochthonous minorities in the process).

The present paper is largely concerned with the latter point, but the two necessarily went hand-in-hand (see de Cillia 1998, chp. 2; Wets 2006, p. 89). Even to date, Austrian German is utilised to index ideological distance to the Germans, e.g., by Austrian comedians. However, an ex-negativo sense of national identity has long been replaced by an autonomous Austrian national identity that has actively been cultivated over the past 75 years. As part of this identity construction, lingual minorities (autochthonous and allochthonous alike) had to give space to the ideal of a monolingual, Austrian-Germanspeaking Austrian. This ideal, however, stands in stark contrast not only to the multilingual heritage of the monarchy, but also to recent migration streams that have effectively rendered present-day Austria an immigrant country, at least since the 1960s.

\section{The Turkish Minority in Austria}

In 2018, 23.3\% of Austria's overall population of $\sim 8.9$ million had a migration background (Statistik Austria 2019, p. 29). Of these, the majority came from EU and EFTA (European Free Trade Association) states (39\%) - spearheaded by Germans-followed by former Yugoslavia (26\%), Turkey (13\%) and "other" states (Statistik Austria 2019, pp. 28-29). Roughly $74 \%$ were first-generation and $26 \%$ were second-generation migrants (The Expert Council for Integration 2019, p. 17). Immigrants from EU and EFTA states were on average first-generation migrants; immigrants from former Yugoslavia and Turkey leaned more towards the second-generation (Statistik Austria 2019, p. 29).

These numbers mirror Austria's recent immigration history, which started to reshape Austria's social landscape from the 1950s and 1960s. In 1961, roughly 100,000 foreign nationals resided in Austria, making up 1.4\% of the overall population (Statistik Austria 2011; 2019, p. 26). From the mid-1960s, in the course of the guestworker treaties with 
former Yugoslavia and Turkey, this number increased to 212,000 (2.8\%) by 1971 and 311,000 (4\%) by 1974 (Statistik Austria 2011, 2019, p. 26). By 1991, Austria counted 518,000 foreign nationals $(6.6 \%$ of its overall population); the further increase was mostly owed to the family reunification of guestworkers from the 1970s. From then, the net migration of Turkish nationals more or less stagnated. There was another increase in immigration from former Yugoslavia in the course of the Yugoslav wars but, on average, immigration from EU states took over from the 2000s (The Expert Council for Integration 2019, p. 19).

When looking at the Turkish minority more specifically, a mere 217 Turkish nationals resided in Austria in March 1961 (Statistik Austria 2011). This number increased to 16,423 by May 1971, to 59,900 by May 1981 and to 118,579 by May 1991. In May 2001, 127,226 Turkish nationals lived in Austria, a mere addition of 8647 when compared to 10 years earlier. The net migration rate diminished even further over the years: in 2018, for the first time after many years, the migration balance with Turkey was negative $(-22)$, meaning that, on average, more Turks emigrated from Austria (The Expert Council for Integration 2019, p. 23).

As of 2018, the annual average of the Turkish minority in Austria was 269,800 (including naturalisations), roughly $3 \%$ of the overall population. Of these, $68,300(44 \%)$ were first-generation and 88,500 (56\%) were second-generation migrants (The Expert Council for Integration 2019, p. 20). Overall, 156,800 were Austrian citizens (58\%), and among the second generation, the percentage was significantly higher (77\%). Judging from these numbers, especially for the second-generation, it is evident that the Turkish minority has become an integral part of Austria's sociopolitical landscape-the majority of them are Austrian citizens and, as such, they are equal to their "autochthonous" peers in front of the state. However, when one looks at their average yearly net income and unemployment rates, it becomes evident that they are generally in a much more precarious socioeconomic position (Statistik Austria 2019, p. 13). In 2018, the average annual net salary/unemployment rates of Austrian citizens were $€ 26,378 / 6.7 \%$ (this would include naturalised Turks); for Turkish citizens they were significantly lower and higher, respectively, at $€ 20,525 / 16.8 \%$ (Statistik Austria 2019, p. 13). This is because Turks in Austria, first and second generation alike, are still comparatively low-skilled workers. This can be attributed to a "sojourner mentality", predominant especially among first-generation Turks, which values early entry into the labour market over long-term social mobility (Pásztor 2014), but the "institutionalised discrimination" of linguistic minorities in Austria's education system plays a big part in this disparity as well (on which see Fereindooni 2011; Gomolla and Radke 2000).

The education system in Austria has long been characterised by an early educational trajectory: primary school takes four years, after which it is decided whether a child can visit an academic high school or the less prestigious Hauptschule. ${ }^{2}$ German-competence has played a large role in the decision if a child can attend academic high school or not, the rationale being that a high level is needed to understand more complex contents taught in monolingual German. Therefore, children of immigrants have had to acquire native-like German to succeed, which, in the context of the children of guestworkers over the past decade, was an almost insurmountable challenge for sociological and linguistic reasons. First, guestworkers were largely unskilled labourers (sometimes illiterate), so their children did not have the same educational support system at home as many of their Austrian peers. Second, the common pattern of language acquisition for second-generation Turks has been predominantly one of sequential bilingualism: Turkish at home, German with entry to kindergarten or primary school (e.g., Pfaff 1993). Four years is hardly enough time for a bilingual child with a relatively late age of onset-primary school normally starts at 6 years old in Austria-to match their monolingual peers. As a result, many Turkish children fell off the educational grid, and the Turkish minority is still over-represented at the lower end of the educational spectrum (Table 1 ).

\footnotetext{
2 Such an early trajectory is prone to reproduce social-class inequalities, as the educational mobility of migrant children has been found to correlate with the time of selection (Pásztor 2014, p. 291; Crul 2013, p. 1392). The "New Middle School" (Neue Mittelschule) in Austria addresses this problem by effectively delaying the selection point by four years. It was implemented in 2012.
} 
Table 1. Highest Educational Background in Austria by Migration Background ${ }^{1}$.

\begin{tabular}{|c|c|c|c|c|}
\hline Type of Education & $\begin{array}{l}\text { Without Migration } \\
\text { Background }\end{array}$ & $\begin{array}{l}\text { With Migr } \\
\text { 1st Gen. }\end{array}$ & $\begin{array}{l}\text { Background } \\
\text { 2nd Gen. }\end{array}$ & Turks \\
\hline \multirow{2}{*}{$\begin{array}{c}\text { Compulsory School } \\
\text { Apprenticeship/Vocational } \\
\text { School }\end{array}$} & $9.7 \%$ & $25.9 \%$ & $21.1 \%$ & $57.5 \%$ \\
\hline & $56.0 \%$ & $32.1 \%$ & $48.0 \%$ & $29.3 \%$ \\
\hline \multirow{2}{*}{$\begin{array}{c}\text { Academic High/Higher } \\
\text { Vocational Schools } \\
\text { University }\end{array}$} & $15.9 \%$ & $19.0 \%$ & $16.8 \%$ & $8.3 \%$ \\
\hline & $18.4 \%$ & $23.0 \%$ & $14.1 \%$ & $4.9 \%$ \\
\hline
\end{tabular}

${ }^{1}$ Data taken from Statistik Austria (2019, p. 53), which is based on employable people in 2018 between 25 and 64 years of age. The "with migration background" cohort is skewed in both directions: First-generation EU/EFTAmigrants are over-represented in the university cohort; former guestworker migrants are over-represented in the compulsory school cohort. First/second-generation data is not available for the Turkish minority.

Despite the obstacles faced, one can observe educational mobility among Turks nonetheless. In 2016, 60.9\% of all employable Turks living in Austria had compulsory school as their highest educational background, and only $4 \%$ had graduated from university (Statistik Austria 2017, p. 51). When compared to the table above, one witnesses an increase of $0.9 \%$ in university graduates in just two years. Second-generation Turks have evidently made a mark with their educational mobility -in particular the women, who often surpass their mothers' highest educational background by two stages and who are often better educated than their male peers (see e.g., Nalborczyk 2012, p. 650); however, there remains quite a significant disparity when they are compared to the national average.

This has contributed to the already existing stigmatisation of the Turkish minority, who, "especially in Austria and Germany, are attributed as having a rural life, marked by patriarchal masculinity and traditionalism" (Koç 2009, p. 104). In Austria, this stigma is often enriched by aggressive depictions reminiscent of the Sieges of Vienna in the 16th and 17th centuries. The below Figure 1 is taken from a local pamphlet that was circulated in the 20th district of Vienna by the Freedom Party of Austria (Freiheitliche Partei Österreichs; FPÖ), a right-wing political party that was part of the coalition governments between 2000 and 2005 and between 2017 and 2019.

In this picture, it is strongly suggested that "the Austrian"- depicted here in traditional clothing - is being overrun by a mob of Turkish infiltrators. Recall that the actual migration balance with Turkey at the time of the publication is negligible; it is ideological warfare, an Austrian ethnic "purity" under threat, and the FPÖ is hinting at it here. To this end, the carriage can be read as a symbol of Umvolkung, or the "forced conversion of ethnic population" (Hofmann et al. 2019, p. 656), a right-wing narrative that equates the mixing of ethnicities-in this case, essentialised Austrians with unwanted immigrants from Turkey-with an infiltration from within or worse, a pest infestation. ${ }^{3}$ (The same party also used "Vienna must not become Istanbul" as one of their slogans in their 2005 election campaign to rail against the EU accession negotiations with Turkey).

It is not that surprising to see such depictions from racist right-wing parties. However, even the Integration Report, published yearly by the Austrian government, attested the following in 2017. 
temmedien. An nur 3 Tagen derselben Woche aber begehrten 900 Personen Asyl in Österreich. Und alleine an dem genannten Wochenende wurden 6.000 geschleppte „Bootsflüchtlinge” vor Südeuropas Küsten gerettet (das ist bei weitem nicht die an diesen zwei Tagen in der EU angekommene Gesamtzahl!).

Man muss nur die bekannten Zahlen hochrechnen, um erstens die verlogene Schlagzeilenpolitik zu durchschauen und zweitens eine Ahnung davon zu bekommen, was unserem Kontinent bevorsteht, wenn die Veranstalter der aggressiven Selbstabschaffung Europas mit ihrem Programm durch sind.

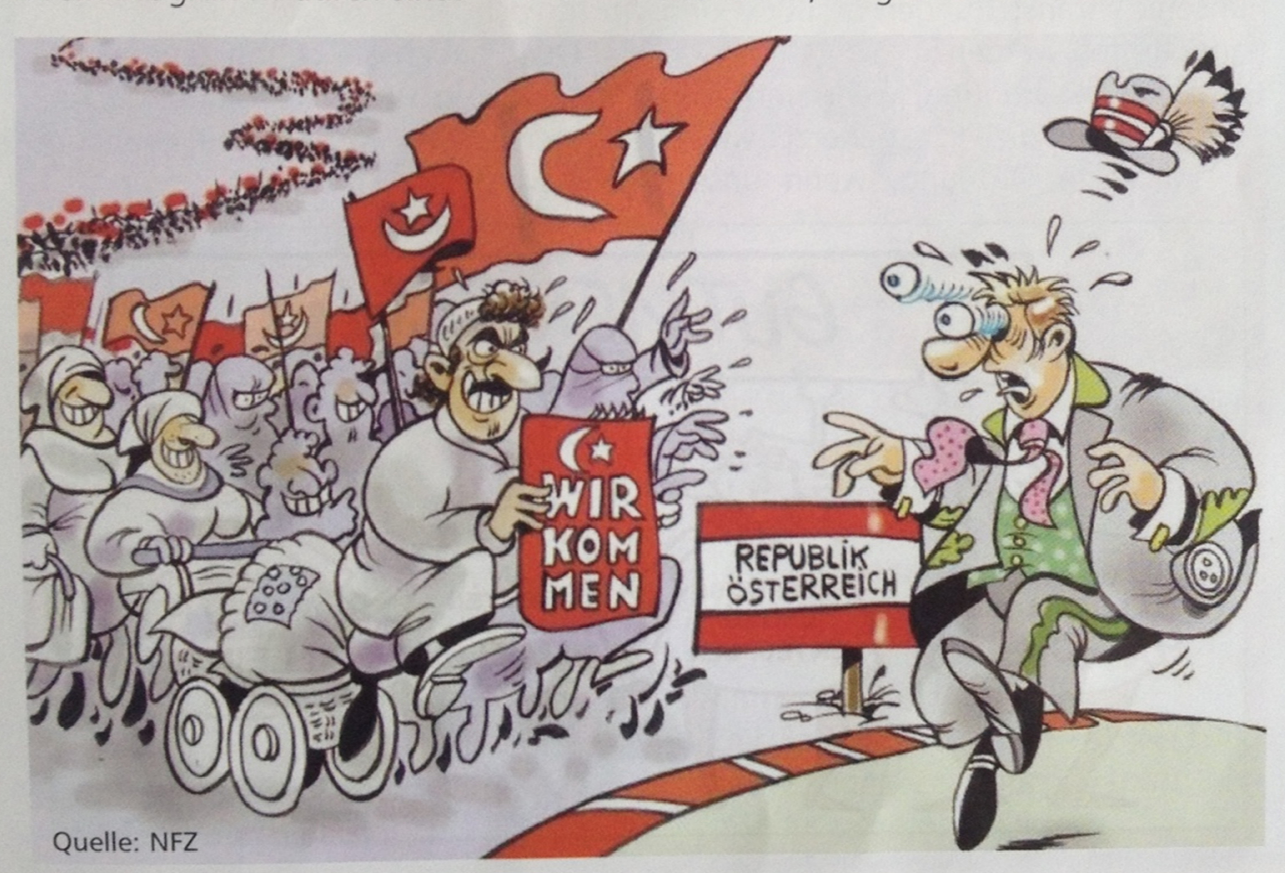

die weit über 1 ! die der österre alljährlich für ċ brennen darf.

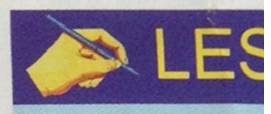

\section{Zum Them Gemeind}

Herr Häupl bauen wieder Wie schön!

Wen meint Die fleißigen ö zahler? Wem I Schlüssel? Den

Denn er sag view, dass die C nug wären, sicl nossenschaftsu können! "Wir" baues reicher. Doch n Mein „Beilei für die kommer

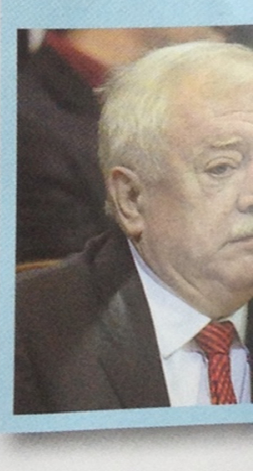

Figure 1. Freedom Party of Austria (Freiheitliche Partei Österreichs; FPÖ) Brigittenau Pamphlet (FPÖ Brigittenau 2015, p. 9.)

Apart from refugee integration, the "traditional" target groups of the integration policy remain the focus of attention. Quite rightly so, because the guestworkers and their descendants are still structurally and emotionally not where they could be based on their long stay in Austria (The Expert Council for Integration 2017, p. 70).

Structural integration can be operationalised comparatively easily by measuring employment rates, mean salaries or highest educational backgrounds, as was done above. However, when it comes to defining and operationalising "emotional" integration, things become more complicated. Partner or spousal choice (Carol et al. 2014; Huschek et al. 2012) are often taken as indicators of how willing a minority is to "mix" with the receptor society, as is "social connection within and between groups in the community" (Ager and Strang 2008, p. 185). However, when the above-cited integration report speaks of "emotional" integration, it mainly refers to an essentialised sense of belonging and the normative expectation of how migrants are expected to "behave" in the receptor society. As mentioned in Section 1, whether integration is perceived to be successful in Austria largely depends on the immigrants' willingness to acculturate. Integration is considered to be a 
one-sided obligation (Wets 2006, p. 89), and it is for Austrians to decide if this obligation has been met or not.

To this end, the Statistical Yearbook, published alongside the Integration Report, publishes data on attitudes towards integration in Austria. In the most recent yearbook of 2019 , over $50 \%$ of the 1000 respondents with Austrian citizenship thought that the integration of migrants in Austria works poorly or very poorly (Statistik Austria 2019, p. 95). Younger respondents were more optimistic, as were those with a lower educational background. Perhaps surprising to many readers, pessimism towards integration in Austria is a phenomenon among the well-educated and higher earners, and this pattern has been reproduced in the Statistical Yearbook since the 2014 issue (Statistik Austria 2019, p. 94).

In contrast, $80 \%$ of the Turkish respondents (both Turkish and Austrian citizens) felt at home in Austria (Statistik Austria 2019, p. 97); 55\% would consider Austria their home; 45\% leaned towards Turkey (Statistik Austria 2019, p. 97)—though the authors acknowledge that these are not necessarily mutually exclusive options. Overall, $83.7 \%$ agreed with "the Austrian way of living", compared to an average of $84.7 \%$ among immigrants (Statistik Austria 2019, p. 105).

One can witness a significant disparity between the two perceptions of the integration climate in Austria. There is, however, little quantitative data beyond what was already shown here that investigates the underlying mechanisms of said disparity. More in-depth attitudinal research that goes beyond self-reporting is needed, and the present paper aims at filling this gap.

\section{Methodology}

One prominent way to quantify attitudes toward ethnic or cultural groups, which has proved reliable over the years, is to study attitudes towards the languages/varieties they speak (Casper 2002; Garrett 2010). This is done on the premise that languages or varieties are highly emblematic or indexical of the people who speak them (Silverstein 1976). Language attitude research has repeatedly shown a "close association between judgements of language and judgements of the people who use the language" (Garrett 2010, p. 10). The distinct advantage of this line of research over classical survey items is that it systematically addresses the risk of social-desirability bias: language attitude studies are typically designed to capture covert rather than overt attitudes, and they do so by comparing differences in evaluations in a controlled setting.

One prominent method of capturing language attitudes is the matched-guise test (MGT) (e.g., Buckingham 2014; Bugel and Santos 2010; Casesnoves Ferrer 2010; Chakrani 2013; Díaz-Campos and Killam 2012; Rindal 2010; Pharao et al. 2014; Loureiro-Rodriguez et al. 2012). One can distinguish between intralingual and interlingual MGTs. The former studies attitudes towards variety differences within a single language, and the latter considers attitudes towards distinct languages (as in the original study of Lambert et al. 1960). In both cases, participants are asked to listen to short speech samples-usually text passages of fairy tales or unmarked natural speech, so as to make sure participants do not respond to the content of the speech samples. Participants are then asked to attribute personality traits to the speakers. They are not made aware of the fact that the two samples are spoken by the same bilingual speaker. Differences in evaluations can then be traced back to the different languages/varieties heard because pitch or other idiosyncratic factors pertaining to the speaker are held constant across the two samples. Social desirability might still skew the numbers, for instance, when participants evaluate stigmatised languages or varieties more positively than they normally would outside a controlled experimental setting. However, differences between the evaluations of the two guises are usually large enough to identify stereotypical tendencies that could be papered over in more conservative study designs.

It has recently been criticised that, when trying to explain the differing evaluations of the two samples spoken by the same individual, it is unclear "which linguistic features exactly were the subject of the attitudes recorded in connection with a certain speech 
sample" (Soukup 2011, p. 349). Intralingual studies have addressed this problem with the help of artificial splicing (e.g., Tyler 2015), where a single variety feature is artificially "spliced into" an already existing speech sample with the help of phonetics software such as Praat. Respondents then evaluate the same sample twice, the only difference being one single variety difference such as alveolar vs. uvular trills. For intralingual studies-like the present study—such elegant solutions are missing, as participants have to evaluate speech samples they sometimes do not even understand, so the probability of them reacting to miniscule differences in pronunciation is comparatively low. It has been found that, in such cases, "evaluations of language varieties do not reflect intrinsic linguistic or aesthetic qualities so much as [ ... ] the levels of status and prestige that they are conventionally associated with in particular speech communities" (Giles and Billings 2004, p. 191). These levels of status and prestige are remarkably robustly captured by MGTs. Even though study participants regularly raise the concern that they cannot evaluate a language they cannot speak or understand, the large effect size generally found in MGTs shows that this does not hinder them from expressing their covert opinions. ${ }^{4}$

To study how Austrian participants view the Turkish minority in Austria, two MGTs were conducted. The first study $(n=155)$ was conducted in 2015. A follow-up study $(n=71)$ was conducted in 2019 to validate the findings of the 2015 study, as well as to test for realtime differences in evaluations, yielding an overall sample size of 226 participants. Four guises were recruited in total to record 60-second samples of Cinderella in German and/or Turkish. Three of the guises (Ilker, Azra and Zeynep) are second-generation bilingual German/Turkish speakers who grew up in Austria. All of them recorded German and Turkish samples (Table 2). For the second study, one additional speaker of Istanbul Turkish (Kemal) was recruited to test for potential differences in the evaluations of different Turkish varieties. ${ }^{5}$

Table 2. Guises for the 2015 and 2019 studies.

\begin{tabular}{ccccc}
\hline Year of Data Collection & German Guise & Turkish Guise & Gender & $\boldsymbol{n}$ \\
\hline \multirow{2}{*}{2015} & Ilker & Ilker & Male & 78 \\
& Azra & Azra & Female & 77 \\
\hline \multirow{2}{*}{2019} & Ilker & Ilker & Male & 36 \\
& Zeynep & Zeynep & Female & 18 \\
& Ilker & Kemal & Male & 17 \\
\hline & & & $\sum 226$ \\
\hline
\end{tabular}

Study participants had to have lived for at least three years in Austria to partake. In both studies, participants were asked to evaluate three guises: the German sample, a distractor sample in a different language (either in French or Croatian, same gender as the guise), and finally, the Turkish sample. Several online questionnaires with either male or female guises were distributed concurrently via social media channels (Facebook and email) by the study author. To ensure sampling diversification, the questionnaires were also distributed to social networks easily accessible to the author. The 2015 study was distributed to a group of volunteer paramedics, a Catholic youth organisation and to a linguistics professor at the University of Vienna who forwarded it to his undergraduate students. Elder participants and other under-represented cohorts were then recruited by snowball sampling. Given the nature of convenience sampling, the study findings allow for limited generalisability: For instance, the findings do not allow us to generalise any

4 Reviewer 3 pointed out that in interlingual designs, the risk of systematic measurement error is comparatively high. For instance, participants could not be responding to the target language, but to foreign languages in general. Therefore, it must be ensured that participants are in fact responding to the target language. In the present study, pre-tests showed that every respondent was able to correctly identify the Turkish sample. Please refer to the discussion for a more in-depth appraisal.

5 In this case, one would technically have to speak of a verbal guise rather than a matched-guise test, as 17 of 71 participants of the 2019 study did not evaluate the same speaker. However, no significant difference was found in the evaluations of the different Turkish varieties. 
findings to the individual states of Austria. To minimise the risk of sampling bias, the study findings were always interpreted in conjunction with relevant literature and Austria's sociopolitical history. Finally, financial incentives were offered in the form of Amazon vouchers: participants could enter a lottery, where, at the end of the data collection, winners were drawn randomly.

Participants were asked to ascribe 14 personality traits to each guise (see Appendix A). Likert scales from 1 to 7 were used to measure if they did not agree at all (1), neither agreed nor disagreed (4) or completely agreed (7) when asked about a specific personality trait. The traits were established qualitatively ahead of the 2015 study. Twenty participants were asked to listen to either Ilker's or Azra's speech samples, either in Turkish or in German, but never to both languages at the same time. They were then asked to describe what they imagine the speaker to be like. After discarding answers that directly related to the reading style, their answers were coded by the author, as well as by two linguists and one economy-alumnus, to ensure inter-rater reliability. The question battery resulting from this process (described in detail in the following section) remained unaltered in the 2019 study to ensure comparability between the two studies.

Table 3 shows the participant demographics. It was already established in the previous section that age and educational background are significant predictors when it comes to attitudes towards the integration climate in Austria. Compulsory school, vocational schools and apprenticeship were coded as "lower", academic high school and higher vocational school were coded as "middle" and university was coded as "higher" educational background. The participants' migration background was included to control for potential ethnic enclave effects (see Pásztor 2014, p. 299). “Confronted with multilingualism” was included to account for urban/rural differences, since significantly more immigrants live in urban areas in Austria (e.g., Statistik Austria 2014, 101ff). Religiousness was included to test for conservativeness: it was found that religious people, especially Catholics and Protestants, can be more prone to prejudice against ethnic minorities than non-religious people (e.g., Scheepers et al. 2002). This effect was not reproduced in the present study.

Table 3. Participant demographics.

\begin{tabular}{|c|c|c|c|c|}
\hline Demographic & Level & 2015 Study & 2019 Study & Total \\
\hline \multirow{3}{*}{ Gender } & Male & $55(35 \%)$ & $19(27 \%)$ & $74(33 \%)$ \\
\hline & Female & $91(59 \%)$ & $52(73 \%)$ & $143(63 \%)$ \\
\hline & NA & $9(6 \%)$ & & $9(4 \%)$ \\
\hline \multirow{3}{*}{ Age } & Mean & 31 & 29 & 30 \\
\hline & Min. & 16 & 15 & 15 \\
\hline & Max. & 74 & 55 & 74 \\
\hline \multirow{3}{*}{$\begin{array}{l}\text { Migration } \\
\text { Background }\end{array}$} & Yes & $37(24 \%)$ & $21(30 \%)$ & $58(26 \%)$ \\
\hline & No & $109(70 \%)$ & $50(70 \%)$ & $159(70 \%)$ \\
\hline & NA & $9(6 \%)$ & & $9(4 \%)$ \\
\hline \multirow{3}{*}{$\begin{array}{l}\text { Confronted with } \\
\text { Multilingualism }\end{array}$} & Yes & $124(80 \%)$ & $56(79 \%)$ & $180(80 \%)$ \\
\hline & No & $20(13 \%)$ & $15(21 \%)$ & $35(15 \%)$ \\
\hline & NA & $11(7 \%)$ & & $11(5 \%)$ \\
\hline \multirow{3}{*}{ Religiousness } & Yes & $43(28 \%)$ & $14(20 \%)$ & $57(25 \%)$ \\
\hline & No & $102(66 \%)$ & $57(80 \%)$ & $159(70 \%)$ \\
\hline & NA & $10(6 \%)$ & & $10(5 \%)$ \\
\hline \multirow{4}{*}{$\begin{array}{c}\text { Education } \\
\text { Parents }\end{array}$} & Higher & $66(43 \%)$ & $34(48 \%)$ & $100(44 \%)$ \\
\hline & Middle & $39(25 \%)$ & $13(18 \%)$ & $52(23 \%)$ \\
\hline & Lower & $42(27 \%)$ & $24(34 \%)$ & $66(29 \%)$ \\
\hline & NA & $8(5 \%)$ & & $8(4 \%)$ \\
\hline \multirow{4}{*}{$\begin{array}{l}\text { Education } \\
\text { Participants }\end{array}$} & Higher & $68(44 \%)$ & $32(45 \%)$ & $100(45 \%)$ \\
\hline & Middle & $64(41 \%)$ & $9(13 \%)$ & $73(33 \%)$ \\
\hline & Lower & $14(9 \%)$ & $30(42 \%)$ & $44(20 \%)$ \\
\hline & NA & $9(6 \%)$ & & $9(4 \%)$ \\
\hline
\end{tabular}


Statistical analysis was performed using the R programming language ( $\mathrm{R}$ Core Team 2020). When specific packages were used for the purpose of analysis or visualisation, they are clearly referenced in the text. For the initial analysis, parametric Welch two-sample $t$-tests were conducted. A two-sample $t$-test allows for a statistical comparison between the evaluations of the Turkish and German guises. As is shown later in this paper, the ascription of personality traits differed significantly between the two guises, and this was the starting point for a more in-depth statistical analysis: an exploratory factor analysis. In layman's terms, an exploratory factor analysis identifies underlying structures or patterns in the data. In the present study, it allows one to reduce the 14 personality traits (see Appendix A) to two underlying "evaluation schemes" or stereotypes: the "archaic migrant" and the "modern European". These extracted factors were then used to fit a linear regression model predicting how xenophobic the study respondents were in their evaluations of the German and Turkish guises.

As linear regression models can paper over more intricate, non-linear mechanisms in the observed data, machine-learning techniques (recursive partitioning trees and random forests) were applied to optimise the predictions of the linear model. Decision tress can make regression models more transparent by hierarchically predicting the outcome variable-in this study, the variable being how xenophobic the participants' evaluation was of the German and Turkish guises-utilising binary branching (for a more detailed discussion, see Breiman et al. 1984). When compared to the linear model, this approach sheds light on more intricate effects pertaining to speaker guise and participant age when it comes to xenophobic attitudes. Finally, to avoid overfitting (Bramer 2007), a random forest regression was subsequently fitted. In layman's terms, random forests aggregate and average over numerous decision trees (in the present study: 500) to create a hierarchy of predictors, such that the closer a variable is to the root of the tree, the more observations are divided into groups on the basis of that variable (for a detailed discussion, see Liaw and Wiener 2002). In the present study, this shows that language, participant age and speaker guise are the most important predictors when it comes to xenophobic evaluations of the speaker guises.

\section{Results}

Table 4 shows the differences in the evaluation of the German and Turkish samples. The significance level was Bonferroni-corrected to control for multiple comparisons: every value not reaching the significance level of 0.0035 was discarded as not significant. Judging by the numbers, it is evident that the evaluations of the German and Turkish guises were significantly different in both studies. The Turkish guises, male and female alike, were evaluated by the respondents to be significantly more aggressive, less educated, less integrated and more religious than the German guises. They were also pictured as being more professional, more family-oriented and more joyous of life. The largest effect sizes were found for the following categories: "Integration", "Religiousness", "Does Not Speak L1 the Whole Day", "Migration Background" and "Is Discriminated Against". In conjunction with the differences in "Professionalism", "Family Orientation" and "Enjoyment of Life", these results reflect the Turkish stereotype outlined in the previous section: the Turkish guises were evaluated as archaic and behind the times, but also as more affectionate-a depiction reminiscent of rural origin (Koç 2009; Lancee and Seibel 2014). 
Table 4. Welch two-sample $t$-test by Language ${ }^{1}$.

\begin{tabular}{|c|c|c|c|c|c|}
\hline Personality Trait & $\begin{array}{l}\text { German } \\
\text { Guise }\end{array}$ & $\begin{array}{l}\text { Turkish } \\
\text { Guise }\end{array}$ & $\begin{array}{c}95 \% \mathrm{CI} \\
\text { Difference }\end{array}$ & $t$ & $p$ (2-Tailed) \\
\hline Non-Aggressiveness & 4.6 & 4.3 & {$[0.2,0.5]$} & 4.3 & $1.84 \times 10^{-5}$ \\
\hline Calmness & 4.4 & 4.4 & {$[-0.2,0.2]$} & n.s. & n.s. \\
\hline Economic Wealth & 3.5 & 3.6 & {$[-0.3,0.1]$} & n.s. & n.s. \\
\hline $\begin{array}{l}\text { Educational } \\
\text { Attainment }\end{array}$ & 5 & 4.5 & {$[0.3,0.7]$} & 5.0 & $8.198 \times 10^{-7}$ \\
\hline Enjoyment of Life & 3.9 & 4.5 & {$[-0.9,-0.4]$} & -5.3 & $1.717 \times 10^{-7}$ \\
\hline Family Orientation & 4.4 & 5 & {$[-0.7,-0.3]$} & -5.7 & $2.636 \times 10^{-8}$ \\
\hline Integration & 4.9 & 3.8 & {$[1.0,1.3]$} & 12.3 & $<2.2 \times 10^{-16}$ \\
\hline Modernism & 4.4 & 4.3 & {$[-0.1,0.2]$} & n.s. & n.s. \\
\hline Professionalism & 4.6 & 5 & {$[-0.6,-0.2]$} & -4.4 & $1.545 \times 10^{-5}$ \\
\hline Religiousness & 3.5 & 4.3 & {$[-1.0,-0.6]$} & -7.3 & $1.558 \times 10^{-12}$ \\
\hline Sympathy & 4.4 & 4.6 & {$[-0.3,0.1]$} & n.s. & n.s. \\
\hline $\begin{array}{l}\text { Does Not Speak L1 the } \\
\text { Whole Day }\end{array}$ & 3.4 & 5.2 & {$[-2.1,-1.4]$} & -9.8 & $<2.2 \times 10^{-16}$ \\
\hline $\begin{array}{c}\text { Has Migration } \\
\text { Background }\end{array}$ & 3.6 & 5.7 & {$[-2.4,-1.8]$} & -12.6 & $<2.2 \times 10^{-16}$ \\
\hline $\begin{array}{c}\text { Is Discriminated } \\
\text { Against }\end{array}$ & 2.9 & 4.6 & {$[-2.0,-1.4]$} & -10.6 & $<2.2 \times 10^{-16}$ \\
\hline
\end{tabular}

Table 5 shows differences in evaluation of the male and female Turkish guises. As in Table 4 above, the significance level was Bonferroni-corrected so that every $p$-value over 0.0035 was discarded as not significant.

Table 5. Welch two-sample $t$-test by speaker gender-Turkish ${ }^{1}$.

\begin{tabular}{cccccc}
\hline Personality Trait & $\begin{array}{c}\text { Female } \\
\text { Guise }\end{array}$ & $\begin{array}{c}\text { Male } \\
\text { Guise }\end{array}$ & $\begin{array}{c}\text { 95\% CI } \\
\text { Difference }\end{array}$ & $t$ & $p$ (2-Tailed) \\
\hline Non-Aggressiveness & 4.4 & 4.2 & {$[0.0,0.5\}$} & n.s. & n.s. \\
Calmness & 4.3 & 4.5 & {$[-0.4,0.1]$} & n.s. & n.s. \\
Economic Wealth & 3.6 & 3.6 & {$[-0.2,0.3]$} & n.s. & n.s. \\
Educational & 4.7 & 4.2 & {$[0.3,0.8]$} & 3.8 & 0.0002 \\
Attainment & 5.0 & 4.2 & {$[0.5,1.0]$} & 5.1 & $7.392 \times 10^{-7}$ \\
Enjoyment of Life & 4.9 & 5.0 & {$[-0.4,0.1]$} & n.s. & n.s. \\
Family Orientation & 4.1 & 3.6 & {$[0.2,0.8]$} & 3.5 & 0.0006 \\
$\quad$ Integration & 4.6 & 4.1 & {$[0.2,0.7]$} & 3.3 & 0.0011 \\
Modernism & 5.3 & 4.8 & {$[0.3,0.8]$} & 4.4 & $1.949 \times 10^{-5}$ \\
Professionalism & 4.1 & 4.3 & {$[-0.5,0.1]$} & n.s. & n.s. \\
Religiousness & 4.7 & 4.5 & {$[0.0 ., 0.5]$} & n.s. & n.s. \\
$\quad$ Sympathy & 5.1 & 5.2 & {$[-0.6,0.3]$} & n.s. & n.s. \\
Does Not Speak L1 the & & & & & n.s. \\
Whole Day & 5.7 & 5.7 & {$[-0.4,0.4]$} & n.s. & n.s. \\
Has Migration & & & & n.s. & \\
Background & 4.4 & & {$[-0.7,0.1]$} & & \\
Is Discriminated & 4.7 & &
\end{tabular}

${ }^{1}$ Likert scale: 1 = do not agree at all, 7 = completely agree, n.s. = not significant.

Compared to the female Turkish guises, the male guises were evaluated as significantly less educated, less joyous of life, less integrated, less modern and less professional. As regards education and professionalism, this disparity reflects the above-mentioned educational mobility of second-generation Turkish women, who often surpass their mothers' highest education by two or more stages, and who are often better educated than their male peers. When it comes to integration, modernism and enjoyment of life, the comparatively harsh evaluation of the male guises fits the stereotype of the "Muslim man"—a predom- 
inant stereotype of someone "who is thought to be backward-minded, patriarchal and fundamentalist, and thus, the antithesis of the enlightened 'Western' man." (Scheibelhofer 2007, p. 317).

To explore these initial results in more depth, a dimension reduction with the help of exploratory factor analysis was conducted. A scree plot suggests extracting two or three factors (parallel analysis: 3, acceleration factor: 2). Both two-factor and three-factor models were fit with orthogonal and oblique rotations, and both warranted the same interpretation. The first two factors account for $49.7 \%$ of the observed variances. A third factor would add a mere extra $9.8 \%$ of explained variance at the expense of the elegance of the two-factor model. The present paper therefore reports on the two-factor model with orthogonal rotation.

Table 6 shows the factor loadings of the two extracted factors. The individual personality traits clearly pattern together in a way that substantiates the Oriental/Occidental dichotomy alluded to above, which deserves some further elaboration here.

Table 6. Exploratory Factor Analysis: Two-Factor Model ${ }^{1}$.

\begin{tabular}{ccc}
\hline Personality Trait & Archaic Migrant & Modern European \\
\hline Non-Aggressiveness & & 0.61 \\
Calmness & & 0.55 \\
Economic Wealth & & 0.69 \\
Educational Attainment & 0.30 & 0.54 \\
Enjoyment of Life & 0.40 & 0.50 \\
Family Orientation & -0.44 & 0.66 \\
Integration & & 0.62 \\
Modernism & & 0.77 \\
Professionalism & 0.49 & \\
Religiousness & & \\
Sympathy & 0.79 & \\
Does Not speak L1 the Whole Day & 0.84 & \\
Has Migration Background & 0.65 & \\
Is Discriminated Against & & \\
\hline
\end{tabular}

${ }^{1}$ Orthogonal rotation, accounting for $49.7 \%$ of the observed variance.

Historically, the relationship between Turkey and Austria has been described as one of "grudging admiration" (Deringil 2007, p. 713). The Ottoman Empire was feared because of its military and political power, but after the failure to take Vienna in 1683, a sense of racial/civilisational superiority arose.

In Austria, the visual portrayal of the "Turkish barbarian" in popular prints and leaflets gave way first to a triumphalist contempt of the long-feared foe and then to frank curiosity as Austria was carried along by the fad of turqueries [Oriental fashion] that swept across Enlightenment Europe. In Austrian popular art depicting the "portraits of nations", the Turks were depicted as the lowest of the European peoples. It was this curiosity shaded with tones of racial/civilisational superiority that was to give birth to the "essential other" (Deringil 2007, p. 713, emphasis in original, footnote omitted).

It is clear that the ideological motif of the Turkish barbarian as opposed to the enlightened Western man lives on in present-day political discourse, for instance, in the above-mentioned FPÖ pamphlet. For this reason, the author decided to name the factors "archaic migrant" and "modern European", respectively, to reflect the Orient/Occident dichotomy that has shaped Europe's conception of "the East" profoundly (Said 1978). Thus, when the evaluations of the guises pattern together in the ways outlined in Table 6, perceptions either conform to the "archaic migrant" or the "modern European" stereotypes. In the case of the "archaic migrant", the guise was depicted as family-oriented, not integrated and religious (this mirrors the results in Table 4). These characteristics applied when respondents thought that the guise also fit in the categories "does not speak their L1 the 
whole day", "has migration background" and, perhaps as a result of this, "is discriminated against". Contrariwise, when evaluations patterned together under "modern European", guises were depicted as non-aggressive, calm, educated, integrated, modern, professional and likeable. Both the archaic migrant and modern European stereotypes were considered to be joyous of life.

The factor loadings of the two factors were used to compute two new variables from the 14 personality traits above. These were then re-scaled to 1-7 to match the Likert scales used in the experiments.

Table 7 shows a linear model predicting the score of the "archaic migrant". Recall that in the Likert scale used, the higher the overall score, the more participants pictured the guise as an archaic migrant. Language, speaker sex and participant date of birth were all significant in the model: if participants listened to the Turkish samples, the score for "archaic migrant" increased the most, namely, by 2.3. If they listened to a female guise, the score increased even further. There was, however, a significant interaction effect: if participants listened to a female Turkish guise, this effect was balanced out. There was also a weak age effect: for every decade after 1940 that the participant was born, the overall score increased by 0.1 . In other words, for someone born in 1990, the score for "archaic migrant" was generally 0.5 higher than for someone born in 1940, all other predictors being equal. Educational background was not significant in the linear model. There was also no significant difference between the 2015 and 2019 studies. All other predictors listed in Table 3 were insignificant as well.

Table 7. Linear Model—Outcome Variable: Archaic Migrant ${ }^{1}$.

\begin{tabular}{ccccc}
\hline Predictor & Estimate & Std. Error & $t$ & $p$ \\
\hline (Intercept) & 2.5 & 0.22 & 11.4 & $<2 \times 10^{-16}$ \\
Turkish & 2.3 & 0.16 & 14.3 & $<2 \times 10^{-16}$ \\
Female Speaker & 0.9 & 0.16 & 5.5 & $7.14 \times 10^{-8}$ \\
Turkish x Female Speaker & -1.1 & 0.21 & -5.0 & $8.31 \times 10^{-7}$ \\
Decade 1940 & 0.1 & 0.04 & 2.1 & 0.04 \\
Higher Education & & & & \\
(Reference) & & & n.s. & n.s. \\
Lower Education & -0.1 & 0.16 & n.s. & n.s. \\
Middle Education & -0.0 & 0.12 & n.s. & n.s. \\
Data Collected in 2019 & -0.1 & 0.16 &
\end{tabular}

${ }^{1}$ Ordinary Least Squares, Adjusted R ${ }^{2}$ : 0.46, Likert scale: $1=$ do not agree at all, $7=$ completely agree.

With an adjusted $\mathrm{R}^{2}$ value of 0.46 , the model is a good fit. However, Figures 2 and 3 show that the linearity assumption papers over more intricate effects, for instance, when it comes to the observed age effect.

In Figure 2, one can witness a steady increase in stereotypical evaluations of the Turkish guises the closer participants are born to the turn of the millennium. The younger the participant, the more stereotypical their evaluations-this was in accordance with what the linear model predicted (Table 7). However, for people born after around 1995, the line plummeted, which means that the youngest study participants no longer seem to view the Turkish guises as archaic migrants. In fact, as the orange and blue lines converge between the scores 3 and 4 , younger participants no longer seem to differentiate between the German and Turkish guises along the archaic migrant/modern European dichotomy.

This finding is reproduced in the following decision tree (Figure 3), which was created with the help of the rpart and rpart.plot packages in R (Therneau and Atkinson 2019). 


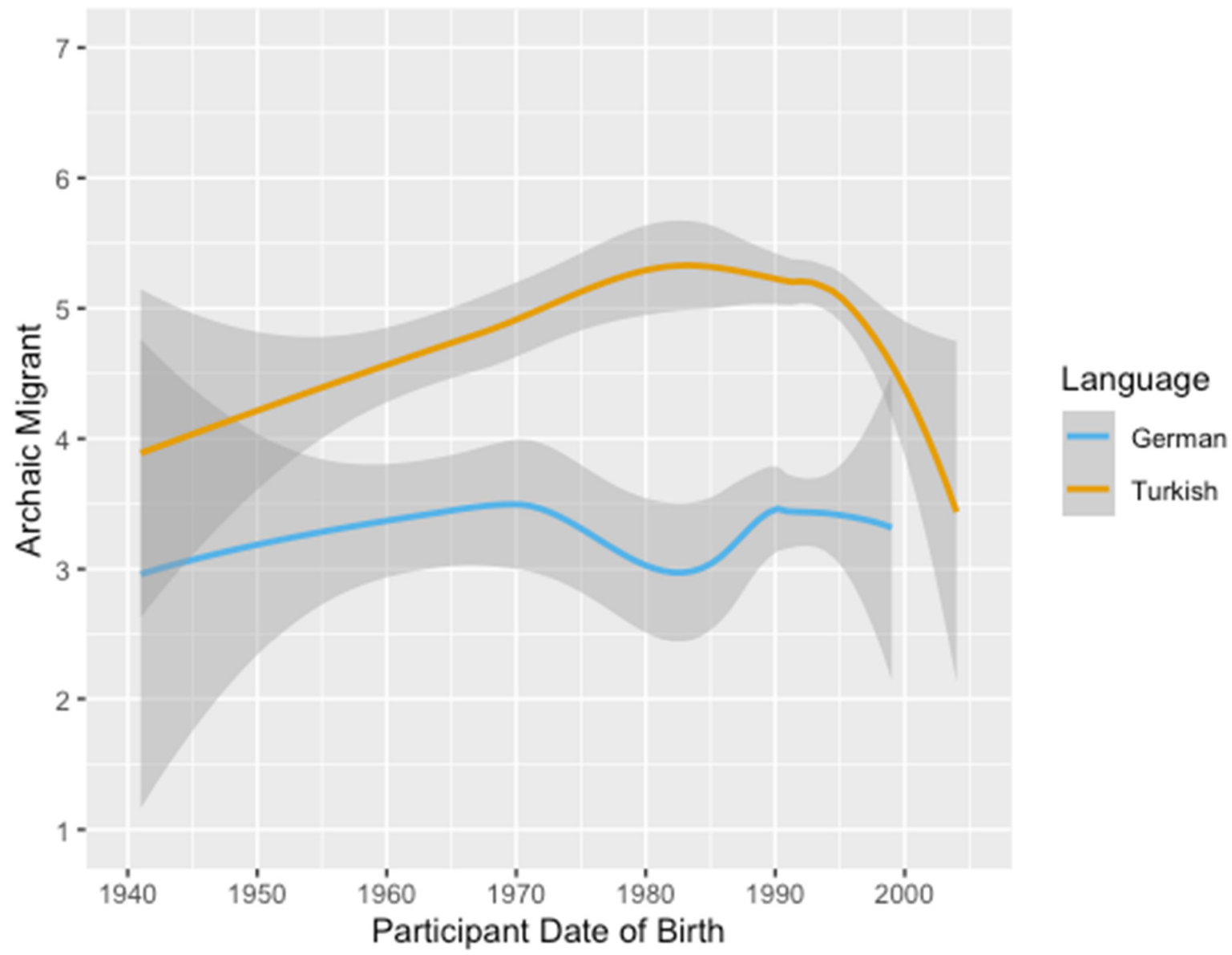

Figure 2. Smoothed conditional means of the "archaic migrant" variable plotted against the "participant date of birth" variable, grouped by language. The grey area shows $95 \%$ confidence intervals. Likert scale: $1=$ do not agree at all, 7 = completely agree. Figure created using the ggplot2 package in R (Wickham 2016).

When it comes to predicting the score of "archaic migrant", the most important distinguishing factor was the language heard. If participants listened to the German samples (left branch of the tree), their average scores of "archaic migrant" ranged between 1.7 and 3.8 (recall that every value under 4 means that they did not picture the guise as an archaic migrant.) Participants responded more favourably when listening to Ilker's German sample. This effect was enhanced for participants born after 1993 whose parents were well educated.

If participants listened to the Turkish samples (right branch of the tree), their average scores ranged between 4.6 and 5.2. For participants born after 1998, the mean score of "archaic migrant" was significantly lower, namely, one full point when compared to participants born between 1971 and 1998. Even though the cohort of respondents born after 1998 was comparatively small $(n=7)$, this effect was reproduced in both studies, speaking to the validity of the claim. 


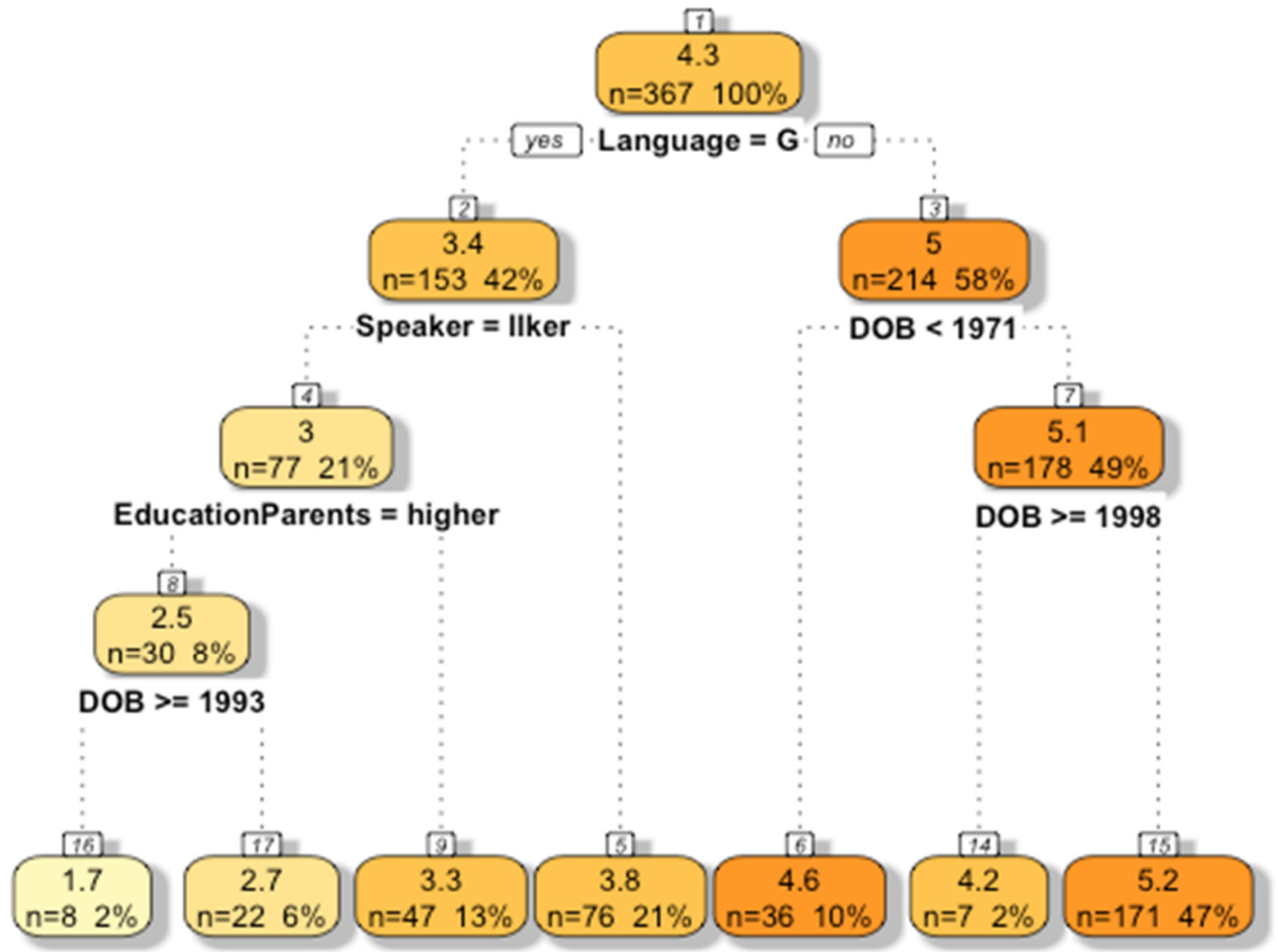

Figure 3. Recursive partitioning tree predicting the "archaic migrant" score. Starting at the root of the tree, the reader can follow the tree downwards by making binary decisions to arrive at the final predicted score. For instance, for a participant born before 1971 who listened to the Turkish guise, the predicted score for "archaic migrant" is 4.6. For an in-depth discussion, see Breiman et al. (1984).

Two tentative conclusions can be drawn from this. The first mirrors the interpretation of Figure 2 above: the youngest participants are significantly less prone to stereotypical answers when listening to the Turkish guises. The second deserves some further elaboration: Participants seem to have responded the most favourably to Ilker's German sample. This is surprising, as he speaks a marked variety of German that is typical of Turkish-German sequential bilinguals. For instance, Darcy and Krüger (2012) found that the Turkish-German sequential bilinguals in their study did not realise the tense/lax distinction of German as strongly as German monolinguals (see also Nimz 2011). This is an interference effect, because Turkish shows no tense/lax distinction at the phonemic level, and Turkish vowels are generally more centralised than German vowels (Darcy and Krüger 2012, pp. 570-71). A preliminary phonetic analysis showed that Ilker likewise only weakly distinguished between [e] and [ $\varepsilon]$ and [a] and [a:], respectively. Such features of Gastarbeiterdeutsch, in conjunction with other stylised features, are normally subject of stigmatisation among the receptor society, especially when it comes to Turkish men realising them (Daszkiewicz 2016). In the present data, however, there seemed to be an inverse effect for younger participants who were socioeconomically well situated.

Why exactly respondents reacted favourably to Ilker is beyond the scope of this paper. What one can say with certainty is that the observed effect was not a statistical artefact. When fitting a random forest that averages over 500 decision trees similar to Figure 3 , the same effect was observed.

The random forest was fitted using the randomForest package in $\mathrm{R}$ (Liaw and Wiener 2002); Figure 4 was created with the help of the randomForestExplainer package. As 
indicated in the figure, most observations were divided into groups on the basis of language heard, participant age and individual guises-long before other predictors were factored in. The model therefore suggests that the preferential treatment of Ilker seems to be independent of his sex.

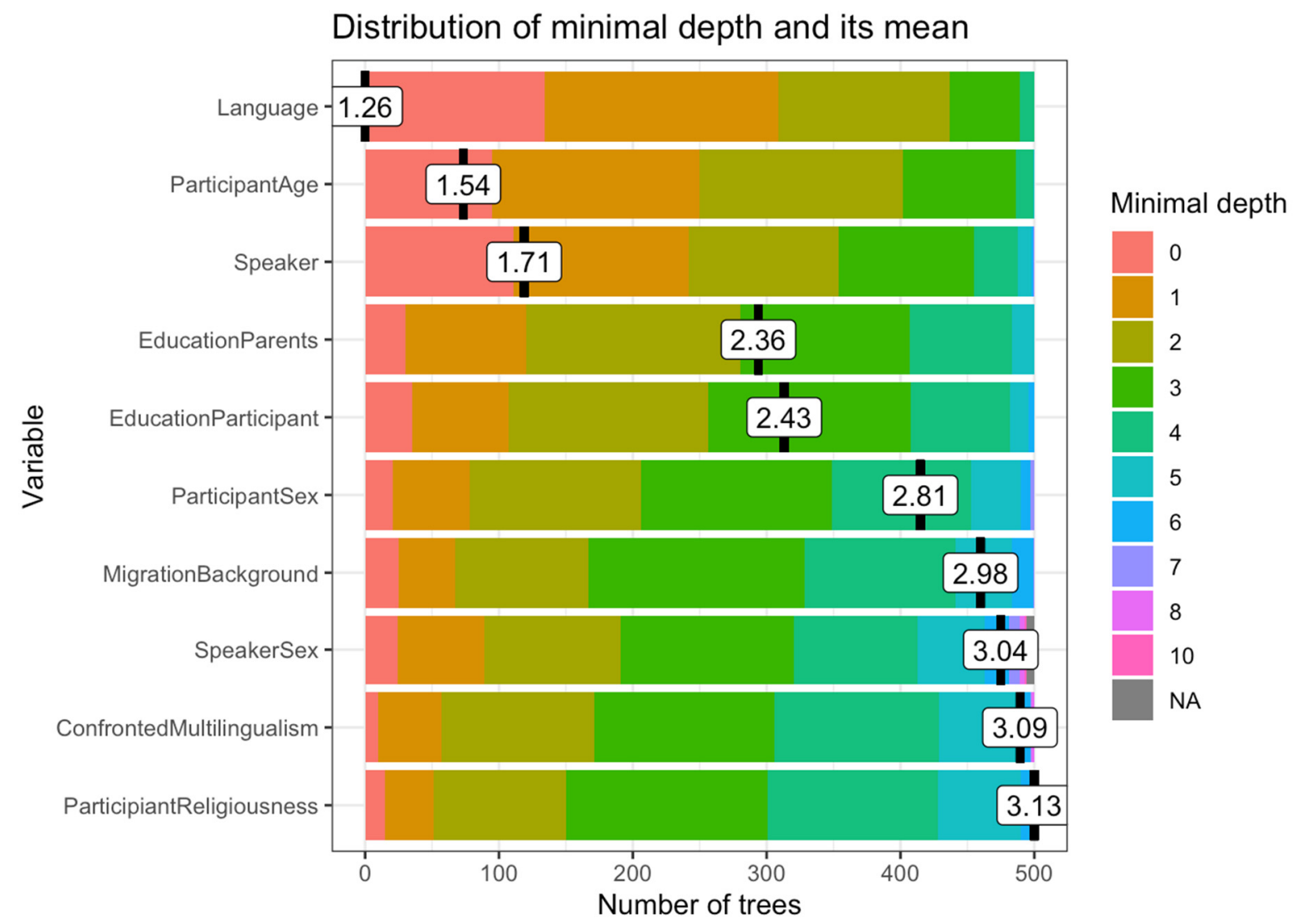

Figure 4. Random forest regression with 500 trees. Mean of squared residuals: 0.98 . $28.3 \%$ of variance explained. The lower the minimal depth of a variable, the closer a variable is to the root of the tree, as shown in Figure 3, and the more observations were divided into groups on the basis of that variable.

\section{Discussion}

The data presented shows that many Austrian participants conceive of the Turkish guises in overall xenophobic terms. They were depicted as more aggressive, less educated, less integrated, more joyous of life and more family-oriented when compared to the German guises. However, this stereotype seems to be less prominent in the evaluation of the female Turkish guises: they were depicted as more educated, more modern and more integrated when compared to the male Turkish guises, whose depictions largely conform to the stereotype of the "Muslim man". In many regards, these evaluations are reminiscent of the ideological motif of the Turkish barbarian that has defined Austria's conception of "the East" for at least three centuries, and that has survived in the present age through sociopolitical discourse around who or what counts as a "real" Austrian.

Statistical analysis also showed that there seems to be an age effect, such that for younger participants, the above-mentioned ideological motif seems to be losing its influence. When interpreted in conjunction with Austria's recent political history (see Section 1), this age effect might actually describe a cohort effect. One can roughly draw a line between participants who were born and bred in a social climate that defined "real" Austrians by their cultural heritage and monolingualism, on the one hand, and participants who grew up in a multilingual environment, on the other hand. As discussed in Sections 2 
and 3, the majority of guestworkers came to Austria between 1970 and 1990, during a time were nation-building propagated homogenisation of the Austrian population under Austrian-German-speakerhood. Guestworkers were a means to an end-cheap labourers that were needed to rebuild from WWII, but they were not considered to be part of the Austrian nation, the key being the word "guest" in "guestworker". The data presented shows that participants born between the 1970s and 1990s were the most xenophobic in their evaluations of Turkish guises. These participants grew up doing a time were many low-skilled Turkish labourers arrived in Austria, and they most profoundly expressed the Orient/Occident dichotomy in their responses. For these participants, the evaluation of the Turkish guises came the closest to the stereotype of the Muslim man as the antithesis to the enlightened Western man (see Scheibelhofer 2007, p. 317)_an important ideological axis of differentiation to separate "real" Christian Austrians from unwelcome migrants from non-elitist Muslim countries (on which see Mandel 2013).

By the turn of the millennium, immigration from Turkey practically ceased. Immigration from prestigious EU countries took over, while former guestworkers became Austrian citizens and sent their children to school. This challenged the ideological motif of the unintegrated Turkish guestworker profoundly. First-generation guestworkers still maintain strong ties to Turkey, often spending extended holidays there. For children of guestworkers, however, their sense of belonging is located at the interface between Turkey and Austria, between their parents' romanticised country of origin and the country in which they spend their everyday lives, and where they work, go to school or attend university. Even though many of them regularly visit family in Turkey, they often find themselves caught between two worlds, feeling that they do not belong either to Austria or Turkey, as they are commonly perceived as quasi-foreigners in both countries. This has opened up space for them to create new diasporic identities that transcend national boundaries (e.g., Scheibelhofer 2007), mediated by their bilingual proficiency in German and Turkish that surpasses their parents' language proficiency.

These new identities have become an integral part of Austria's social landscape over the past 20 years. The empirical data presented in the paper shows that younger participants - that is, those who were born after the large-scale migration streams of the late 20th century-were much more lenient in their evaluations of Turkish speakers. In fact, the data suggests that for these participants, the Orient/Occident distinction mentioned above no longer seems to dictate their perception.

As with every quantitative study, the statistical predictions presented in this paper should be taken with a grain of salt. The described age effect stands and falls with a relatively small cohort: the recursive partitioning tree in Figure 3, for instance, singles out a mere seven participants born after 1998 whose score of "archaic migrant" was significantly lower when compared to participants born between 1971 and $1998(n=171)$. Still, this effect was reproduced in both the 2015 and the 2019 studies, speaking to the validity of the claim. Other machine-learning techniques - in the case of this paper, random forests-likewise strongly indicated the importance of participant age: it was the second most important predictor when it came to predicting the overall score of "archaic migrant", the first being language, i.e., German or Turkish, and the third being the individual guise (see Figure 4).

As indicated in Figure 2, the peak of stereotypical attitudes towards the Turkish speakers was found for participants born around the mid-1980s. This stands testament to the fact that the integration climate in Austria is still comparatively harsh. There is still a strong disparity between "autochthonous" Austrians' and guestworker immigrants' assessment of the integration climate in Austria (see Section 2). The majority of the former think that the integration of migrants works poorly or very poorly, whereas the vast majority of the latter feel at home in Austria. The data presented in this paper postulates a reverse-trend for younger participants, which is in accordance with official altitudinal data published by the Austrian government (see Section 2). However, more research in the near future is needed to validate if the youngest generation's open-mindedness stands the test of time. 
As things stand, for younger participants, being Austrian and being multilingual no longer seem to be mutually exclusive. Preliminary results suggest that these participants also responded favourably to a marked German accent that showed features of guestworker German or Gastrarbeiterdeutsch. As outlined in Section 1, the cultivation of an Austrian-German variety served as an important ideological vehicle to distance Austria from Germany, and Austrians from Germans, after WWII. Allochthonous and autochthonous varieties were erased in favour of a distinct variety of German that was standardised from 1951, when the first Austrian-German dictionary was published. Deviations from Standard-Austrian-German-"ethnolects"-have been the subject of ridicule, as for instance in popular media, where such ethnolects have been commonly used to portray identities that deviate from the idealised Austrian (for examples in the context of Germany, see e.g., Daszkiewicz 2016). Younger participants, however, seem to be less "strict" when it comes to Austrian-German, at least when it comes to interference effects. They responded the most favourably to Ilker's German sample, even though a preliminary phonetic analysis showed that his German-accent is characterised by Turkish interference effects pertaining to the realisation of tense and lax vowels. The current study design does not permit an answer to why exactly Ilker was favoured over the other guises. A follow-up study more geared towards answering such sociophonetic questions is needed to get a more conclusive answer.

Finally, methodological limitations should be discussed. Typically, matched-guise tests are conducted in diglossic settings (e.g., Lambert et al. 1960), in which case, it is safe to assume that participants can correctly identify the language they are asked to evaluate. The present study is original in that participants were asked to evaluate a language that is spoken by only roughly $3 \%$ of Austria's population. The majority of participants could not understand the language they were asked to evaluate. In this case, there is risk of systematic measurement error. Respondents could have reacted to foreign languages in general rather than to Turkish specifically. ${ }^{6}$ To mitigate this source of potential error, after conducting the pre-tests for the 2015 study, participants were asked to identify the languages heard (including distractor samples). All of them were able to correctly identify Turkish. Turkish is a comparatively salient language in the sociolinguistic landscape of Austria, particularly in larger cities. This is why it was deemed reasonable to assume that participants could recognise Turkish when they heard it. Future studies should control for this source of error more thoroughly, however. Signposting the individual languages in the questionnaire (such as Sample 1-German, Sample 3-Turkish) could provoke social desirability bias (see Section 3), but participants could be asked to identify languages retrospectively. This way, every respondent who could not correctly identify Turkish could be excluded from the final analysis.

\section{Conclusions}

The described indexical shift in evaluations of Turkish-from guestworkers to "quasiforeigners" - can be construed as an epiphenomenon of a changing sociopolitical landscape in Austria altogether. Although depictions of the Turkish guises were still comparatively stereotypical, the stigma of the Turkish guestworker slowly seems to be losing its influence. The data presented in this paper suggests that Austrian participants seem to be "children of their time". How they construed Turkish, and by implication, speakers of Turkish, seemed to correlate with the sociopolitical surroundings they grew up in, which significantly constrained how they perceived issues pertaining to immigration, belonging and legitimacy as Austrian citizens. While participants born between the 1970s and 1990s seemed to conceive of Turkish, and by implication the Turkish minority, along the lines of an Orient/Occident dichotomy, younger participants seemed to have moved away from post-WWII ideals of nation building that foregrounded ethnic homogeneity and monolingualism.

\footnotetext{
6 I would like to express my gratitude to Reviewer 3 for pointing this out to me.
} 
Funding: This research was funded by the Arts and Humanities Research Council, grant number AH/L503915 (2017-2019).

Informed Consent Statement: Two institutional review boards reviewed the studies: 2015 studyUniversity of Southampton, \#14442, approved April 2015; 2019 study-University of Edinburgh, \#232-1819/1, approved February 2019.

Data Availability Statement: Data available upon request.

Acknowledgments: Special thanks to my guises, especially Ilker, Zeynep, Azra and Kemal, who agreed to meet with me, have their voices recorded and patiently speak the same text for $>20$ times. I appreciate you having done this in your free time, and the paper would not have been possible without your help. I would also like to express my gratitude to the 3 anonymous reviewers and to Chris Öffel for providing critical feedback on the data analysis, especially when it comes to the applied machine learning techniques.

Conflicts of Interest: The author declares no conflict of interest.

\section{Appendix A. English Translation of the MGT Questionnaire}

Please indicate which personality traits you would attribute to the speaker $(1=$ do not agree at all, $7=$ completely agree):

The speaker...

CALMNESS

... has a balanced personality.

... thinks before he/she acts.

... is sober-minded.

... is patient.

... is thoughtful.

\section{ENJOYMENT OF LIFE}

... is motivated.

... is full of energy.

... is vital.

... is lively.

... tackles challenges with much blood, sweat and tears.

MODERNISM

... has a modern life.

... engages with new technology.

... is liberal.

... keeps up with the times.

... is up to date.

... is progressive.

PROFESSIONALISM

... knows what he/she does.

... seems like an expert.

... knows what he/she wants.

... is determined.

... is confident.

$\ldots$ is resolute.

... is decisive.

... manages his/her life well.

FAMILY ORIENTATION

... prioritises family.

... lives in a household with family.

... is in a relationship. 
... wants to have kids.

... cares about his/her parents.

NON-AGGRESSIVENESS

... avoids physical confrontations (e.g., brawls).

... is in command of his/her physical and emotional self-control.

... is cautious.

... is peace-loving.

... cannot be angry with somebody for long.

SYMPATHY

$\ldots$ is friendly and nice.

... is willing.

... is accommodating.

... is trusting.

... is inviting.

$\ldots$ is an open person.

... is funny.

INTEGRATION

... feels that he/she belongs to the Austrian nationality.

... shares Austrian norms, values and attitudes.

... is well integrated into the Austrian education system and the job market.

... deals with Austrian domestic policy.

\section{ECONOMIC WEALTH}

... lives in a big flat.

... has considerable economic reserves.

... could finance a longer overseas stay for his/her children.

... drives an expensive car.

... lives a life of luxury.

... earns good money.

\section{RELIGIOUSNESS}

... is devout.

... goes to church regularly.

... orients his/her life in the direction of his/her belief.

$\ldots$ is spiritual.

\section{EDUCATIONAL ATTAINMENT}

... has finished school without having to repeat a grade.

... managed school well without any need for extra tuition.

... likes to read.

... has a high level of education.

... is studious.

... comes from a bourgeois family.

MISCELLANEOUS

... has a migration background (either the speaker himself/herself or his/her parents were born in a foreign country).

... does not speak his/her first language the whole day.

... is discriminated against in everyday life on the grounds of his/her age, gender and/or ethnicity.

\section{References}

Ager, Alastair, and Alison Strang. 2008. Understanding Integration: A Conceptual Framework. Journal of Refugee Studies 21: 166-91. [CrossRef]

Bramer, Max. 2007. Avoiding Overfitting of Decision Trees. In Principles of Data Mining. London: Springer, pp. 119-34. 
Breiman, Leo, Jerome Friedman, Charles J. Stone, and R. A. Olshen. 1984. Classification and Regression Trees. Wadsworth: Taylor \& Francis.

Buckingham, Louisa. 2014. Attitudes to English teachers' accents in the Gulf. International Journal of Applied Linguistics 24: 50-73. [CrossRef]

Bugel, Talia, and Hélade Scutti Santos. 2010. Attitudes and representations of Spanish and the spread of the language industries in Brazil. Language Policy 9: 143-70. [CrossRef]

Carol, Sarah, Evelyn Ersanilli, and Mareike Wagner. 2014. Spousal Choice among the Children of Turkish and Moroccan Immigrants in Six European Countries: Transnational Spouse or Co-ethnic Migrant? International Migration Review 48: 387-414. [CrossRef]

Casesnoves Ferrer, Raquel. 2010. Changing linguistic attitudes in Valencia: The effects of language planning measures. Journal of Sociolinguistics 14: 477-500. [CrossRef]

Casper, Klaudia. 2002. Spracheinstellungen. Theorie und Messung. Norderstedt: Books on Demand.

Chakrani, Brahim. 2013. The impact of the ideology of modernity on language attitudes in Morocco. The Journal of North African Studies 18: 431-42. [CrossRef]

Crul, Maurice. 2013. Snakes and Ladders in Educational Systems: Access to Higher Education for Second Generation Turks in Europe. Journal of Ethnic and Migration Studies 39: 1381-401. [CrossRef]

Darcy, Isabelle, and Franziska Krüger. 2012. Vowel perception and production in Turkish children acquiring L2 German. Journal of Phonetics 40: 568-81. [CrossRef]

Daszkiewicz, Anna. 2016. Orts- und situationsgebundener Sprachgebrauch: Zum Gastarbeiterdeutsch türkischstämmiger MigrantInnen und zu seiner medialen Repräsentation. Białostockie Archiwum Językowe 16: 75-94. [CrossRef]

de Cillia, Rudolf. 1998. Burenwurscht Bleibt Burenwurscht: Sprachenpolitik und Gesellschaftliche Mehrsprachigkeit in Österreich. Klagenfurt: Drava-Verlag.

de Cillia, Rudolf, and Ruth Wodak. 2006. Ist Österreich ein "Deutsches" Land? Sprachpolitik und Identität in der Zweiten Republik. Innsbruck/Wien/Bozen: Studien Verlag.

Deringil, Selim. 2007. The Turks and 'Europe': The Argument from History. Middle Eastern Studies 43: 709-23. [CrossRef]

Díaz-Campos, Manuel, and Jason Killam. 2012. Assessing Language Attitudes through a Matched-guise Experiment: The Case of Consonantal Deletion in Venezuelan Spanish. Hispania 95: 83-102.

Fereindooni, Karim. 2011. Schule—Migration—Diskriminierung: Ursachen der Benachteiligung von Kindern mit Migrationshintergrund im Deutschen Schulwesen. Wiesbaden: VS Verlag für Sozialwissenschaften/Springer Fachmedien Wiesbaden GmbH.

FPÖ Brigittenau. 2015. Klartext in Blau: Brigittenau. Available online: https:/ / brigittenau.fpoe-wien.at/fileadmin/user_upload/www. fpoe-wien.at/Unterorganisationen/brigittenau.fpoe-wien.at/Klartext-2015/Klartext-2015-02.pdf (accessed on 19 March 2021).

Gal, Susan. 2016. Sociolinguistic differentiation. In Sociolinguistics: Theoretical Debates. Edited by Nikolas Coupland. Cambridge: Cambridge University Press, pp. 113-35.

Garrett, Peter. 2010. Attitudes to Language. Cambridge: University Press.

Giles, Howard, and Andrew C. Billings. 2004. Assessing Language Attitudes: Speaker Evaluation Studies. In The Handbook of Applied Linguistics. Edited by Alan Davies and Catherine Elder. Oxford: Blackwell Publishing, pp. 187-209.

Gogolin, Ingrid. 1994. Der Monolinguale Habitus der Multilingualen Schule. Münster and New York: Waxmann.

Gomolla, Mechtild, and Frank-Olaf Radke. 2000. Mechanismen institutionalisierter Diskriminierung in der Schule. In Migration, Gesellschaftliche Differenzierung und Bildung. Edited by Ingrid Gogolin and Bernhard Nauck. Opladen: Leske \& Budrich.

Groenewold, George, Helga A. G. de Valk, and Jeroen van Ginneken. 2014. Acculturation Preferences of the Turkish Second Generation in 11 European Cities. Urban Studies 51: 2125-42. [CrossRef]

Hofmann, Julia, Carina Altreiter, Jörg Flecker, Saskja Schindler, and Ruth Simsa. 2019. Symbolic struggles over solidarity in times of crisis: Trade unions, civil society actors and the political far right in Austria. European Societies 21: 649-71. [CrossRef]

Huschek, Doreen, Helga A. G. de Valk, and Aart C. Liefbroer. 2012. Partner Choice Patterns Among the Descendants of Turkish Immigrants in Europe. European Journal of Population 28: 241-68. [CrossRef]

Kagitcibasi, Cigdem. 2010. Changing Life Styles-Changing Competencies: Turkish Migrant Youth in Europe. Historical Social Research 35: 151-68.

Koç, Günes. 2009. Turkish Migrants in Austria and Germany: Stereotypes and Xenophobia. In Turks in Europe: Culture, Identity and Integration. Edited by Talip Küçükcan and Veyis Güngoör. Amsterdam: Turkevi Research Centre, pp. 103-28.

Lambert, Wallace E., R. C. Hodgson, C. Gardiner, and S. Fillenbaum. 1960. Evaluational Reactions To Spoken Languages. Journal of Abnormal and Social Psychology 9: 44-51. [CrossRef]

Lancee, Bram, and Verena Seibel. 2014. Does Rural Origin Affect Immigrants' Contact with Natives? A Study of Turks in Six European Countries. Journal of Ethnic and Migration Studies 40: 1331-53. [CrossRef]

Liaw, Andy, and Matthew Wiener. 2002. Classification and Regression by randomForest. R News 2: 18-22.

Loureiro-Rodriguez, Veronica, May M. Boggess, and Anne Goldsmith. 2012. Language Attitudes in Galicia: Using the Matched-guise Test among High School Students. Journal of Multilingual and Multicultural Development 34: 136-53. [CrossRef]

Mandel, Ruth. 2013. Fifty Years of Migration, Fifty Years of Waiting: Turkey, Germany and the European Union. German Politics and Society 31: 66-78. [CrossRef]

Nalborczyk, Agata S. 2012. Nermin Abadan-Unat, Turks in Europe: From Guest Worker to Transnational Citizen. International Sociology 27: 649-52. [CrossRef] 
Nimz, Katharina. 2011. Vowel Perception and Production of Late Turkish Learners of L2 German. Paper presented at the 17th International Congress of Phonetic Sciences (ICPhS XVII), Hong Kong, China, August 17-21.

Pásztor, Adél. 2008. The children of guest workers: Comparative analysis of scholastic achievement of pupils of Turkish origin throughout Europe. Intercultural Education 19: 407-19. [CrossRef]

Pásztor, Adél. 2014. Education matters: Continuity and change in attitudes to education and social mobility among the offspring of Turkish guest workers in the Netherlands and Austria. International Studies in Sociology of Education 24: 290-303. [CrossRef]

Pfaff, Carol W. 1993. Turkish language development in Germany. In Immigrant Languages in Europe. Edited by Guus Extra and Ludo Verhoeven. Clevedon: Multilingual Matters, pp. 119-46.

Pharao, Nicolai, Marie Maegaard, Janus Spindler Møller, and Tore Kristiansen. 2014. Indexical meanings of [s+] among Copenhagen youth: Social perception of a phonetic variant in different prosodic contexts. Language in Society 43: 1-31. [CrossRef]

R Core Team. 2020. R: A Language and Environment for Statistical Computing. Vienna: R Foundation for Statistical Computing.

Rindal, Ulrikke. 2010. Constructing identity with L2: Pronunciation and attitudes among Norwegian learners of English. Journal of Sociolinguistics 14: 240-61. [CrossRef]

Said, Edward. 1978. Orientalism. New York: Random House.

Scheepers, Peer, Mèrove Gusberts, and Evelyn Hello. 2002. Religiosity and Prejudice Against Ethnic Minorities in Europe: CrossNational Tests on a Controversial Relationship. Review of Religious Research 43: 242-65. [CrossRef]

Scheibelhofer, Paul. 2007. His-stories of Belonging: Young Second-Generation Turkish Men in Austria. Journal of Intercultural Studies 28: 317-30. [CrossRef]

Silverstein, Michael. 1976. Shifters, Linguistic Categories, and Cultural Description. In Meaning in Anthropology. Edited by Keith H. Basso and Henry A. Selby. Albuquerque: University of New Mexico Press, pp. 11-55.

Sonntag, Niklas. 2010. Minderheiten und Recht. Eine Einführung am Beispiel Österreichs. Europäisches Journal für Minderheitenfragen 3: 4-32. [CrossRef]

Soukup, Barbara. 2011. Austrian listeners' perceptions of standard-dialect style-shifting: An empirical approach. Journal of Sociolinguistics 15: 347-65. [CrossRef]

Statistik Austria. 2011. Bevölkerung nach Staatsangehörigkeit und Geschlecht 1951 bis 2011. Available online: https: //www.statistik.at/web_de/statistiken/menschen_und_gesellschaft/bevoelkerung/volkszaehlungen_registerzaehlungen_ abgestimmte_erwerbsstatistik/bevoelkerung_nach_demographischen_merkmalen/022884.html (accessed on 19 March 2021).

Statistik Austria. 2014. Statistical Yearbook 2014. Available online: https://www.bmeia.gv.at/fileadmin/user_upload/Zentrale/ Integration/Integrationsbericht_2014/migration_integration2014-web.pdf (accessed on 19 March 2021).

Statistik Austria. 2017. Statistical Yearbook 2017. Available online: https://www.bmeia.gv.at/fileadmin/user_upload/Zentrale/ Integration/Integrationsbericht_2017/Statistisches_Jahrbuch_2017.pdf (accessed on 19 March 2021).

Statistik Austria. 2019. Statistical Yearbook 2019. Available online: https://www.bmeia.gv.at/fileadmin/user_upload/Zentrale/ Integration/Integrationsbericht_2019/Migration-Integration-2019.pdf (accessed on 19 March 2021).

Strabac, Zan, Ola Listhaug, and Tor Georg Jakobsen. 2012. Patterns of Ethnic Intolerance in Europe. Journal of International Migration and Integration 13: 459-79. [CrossRef]

The Expert Council for Integration. 2017. Integration Report 2017. Available online: https://www.bmeia.gv.at/fileadmin/user_ upload/Zentrale/Integration/Integrationsbericht_2017/Integration_Report_2017_English_.pdf (accessed on 19 March 2021).

The Expert Council for Integration. 2019. Integration Report 2019. Available online: https://www.bmeia.gv.at/fileadmin/user_ upload/Zentrale/Integration/Integrationsbericht_2019/IB2019_EN_web.pdf (accessed on 19 March 2021).

Therneau, Terry, and Beth Atkinson. 2019. rpart: Recursive Partitioning and Regression Trees. Available online: https:/ CRAN.Rproject.org / package=rpart (accessed on 19 March 2021).

Tyler, Joseph C. 2015. Expanding and Mapping the Indexical Field: Rising Pitch, the Uptalk Stereotype, and Perceptual Variation. Journal of English Linguistics 43: 284-310. [CrossRef]

Wets, Johan. 2006. The Turkish Community in Austria and Belgium: The Challenge of Integration. Turkish Studies, 85-100. [CrossRef]

Wickham, Hadley. 2016. ggplot2: Elegant Graphics for Data Analysis. New York: Springer.

Zick, Andreas, Thomas F. Pettigrew, and Ulrich Wagner. 2008. Ethnic Prejudice and Discrimination in Europe. Journal of Social Issues 64: 233-51. [CrossRef] 